Proceedings of the 2019 International Scientific Conference 'Economic Sciences for Agribusiness and Rural Economy' No 3, Warsaw, 5-7 June 2019, pp. 95-102

\title{
THE ROLE OF NUTRIA MEAT PRODUCTION IN THE CONTEXT OF UKRAINE FOOD SECURITY
}

\author{
Olena Pavlenko, $\mathrm{PhD}^{1 *}$; Olga Babytska, $\mathrm{PhD}^{2^{* *}}$; Olena Berbenets, $\mathrm{PhD}^{3^{* * *}}$, \\ Tamara Prykhodko ${ }^{4 * * *}$; Olga Zhmaylova, $\mathrm{PhD}^{5^{* * * * *}}$
}

\author{
${ }^{1}$ Department of Economics, Dnipro State Agrarian and Economic University \\ ${ }^{2}$ Department of Economics and Economic Theory, Bila Tserkva National Agrarian University \\ ${ }^{3}$ Department of Management, Public Management and Administration, Dnipro State Agrarian and Economic University \\ ${ }^{4}$ Department of Economics and Economic Theory, Bila Tserkva National Agrarian University \\ ${ }^{5}$ Department of Statistics, Analysis and Marketing, Sumy National Agrarian University \\ ${ }^{*}$ https://orcid.org/0000-0003-3557-3338 \\ ${ }^{* *}$ https://orcid.org/0000-0002-1388-3071 \\ *** https://orcid.org/0000-0001-9785-6179 \\ **** https://orcid.org/0000-0002-1802-441X \\ ${ }^{* * * * *}$ https://orcid.org/0000-0002-1157-1453
}

\begin{abstract}
The article presents the role and potential of the nutria breeding development as an alternative livestock sector in the context of Ukraine's food security. A comparative analysis of qualitative characteristics of meat by species of animals was conducted. The efficiency of nutria breeding by types of enterprises with a short-term forecast is analysed. By expert evaluations determined the weight of the five main problems of the industry, which constitute the next steps of a comprehensive research of nutria breeding.
\end{abstract}

Key words: food security, meat production, nutria breeding, effectiveness of production, expert evaluations JEL codes: C13, C43, O13, Q12, Q18

\section{INTRODUCTION}

The basis for maintaining food security is always in all countries of the world is the development of its own agricultural production in order to become the main source of food supplies. There is enough capacity in the world to produce food in such amount as to provide everyone with adequate nutrition; in spite of the successes achieved over the last two decades, 805 million people, or every ninth inhabitant of the planet, continue to suffer from chronic hunger (Vasylieva, 2018). According to the words of the FAO DirectorGeneral Jose Graziano da Silva: "The destruction of hunger requires commitment of everyone: neither

${ }^{1}$ Corresponding author: .Efremova 25, Dnipro, Ukraine, es.pavlenko17@gmail.com

${ }^{2}$ Corresponding author: Soborna Sq.8/1, Bila Tserkva, Ukraine, babitskaya_olga@ukr.net

${ }^{3}$ Corresponding author: Efremova 25, Dnipro, Ukraine, lenaberbenets@gmail.com

${ }^{4}$ Corresponding author: Soborna Sq. 8/1, Bila Tserkva, Ukraine, ratamy@bigmir.net

${ }^{5}$ Corresponding author: Kondratyeva 160, Sumy, Ukraine, zhmaylova_olga@ukr.net 
FAO nor any other institution will be able to win this battle alone" (FAO, 2018), it should be noted that each country must take responsibility for bringing all the opportunities to improve the situation inside the state and help others.

The Ukrainian agrarian sector with potential for production, which significantly exceeds the domestic market needs, can promote the national economy development and its effective integration into the world economy, and consequently, an income increase of the rural population, involved in the agrarian economy, which accounts for more than one third of the country total population, and it also can provide a multiplier effect on other sectors of the national economy development (Regulation of Cabinet of Ministers of Ukraine No 806-r, 2013). But in crisis conditions, due to constant civil strives, lack of legal environment, weakness of state power, a country with huge potential, loses impulse for self-development, and as a result - loses stability.

The issues of food security were studied by Kyrylenko (2014), Vasylieva (2018), Pogrishhuk (2019) and Zaliznjuk (2019). Besides the meat production included nutria breeding was discussed by Volkov (1983) and Parhomec' (2015). The methodology of expert evaluations was describe by Grabovec'kyj (2010).

\section{GOAL AND RESEARCH METHODS}

Investigation of the role, opportunities and problems of the development of the nutria breeding industry as an alternative to livestock industry with the goal of increasing meat products supply to Ukraine population in the food security system.

The study is based on data from the Food and Agriculture Organization of the United Nations, the Ukraine State Statistics Service, the Dnipropetrovsk region enterprises' reports on the food situation and the meat products production, including nutria meat. The correlation and regression analysis and trend lines were used to determine the development trends, and the method of expert evaluations was used to identify the main factors of the industry development problems and to establish the degree of opinions consistency.

\section{RESULTS AND DISCUSSION}

Food security is the food production state in a country that can fully meet the proper quality food needs of society every member, provided it is balanced and accessible to every member of society. The main indicators of food security include: daily caloric diet of humans; the production and consumption ratio of meat and meat products, milk and dairy products, eggs, sugar, potatoes, vegetables and food melons per capita; grain production per capita per year; the cereal stocks level by the end of the period and the share of sales of imported food products through the trade network of enterprises (Pogrishhuk, 2019).

Assessments of Ukraine's food security level are made on indicators, operated by the FAO, as well as in accordance with the methodology approved by the Ukraine Cabinet of Ministers order "Some food security issues" from 05.12.2007 No 1379 (FAO, 2018). According to these standards, the daily energy value of a human diet is defined as the products sum of a mass unit of some products, consumed by a human during the day, and their energy value. The limit criterion is set at $2,500 \mathrm{kcal}$ per day, while $55 \%$ of the daily ration should be provided by the consumption of animal origin products (Table 1).

In 2017 , in Ukraine $29 \%$ of the average human daily ration was provided by consumption of livestock products. Thus, on average, the EU-28 calorie content is $3,400 \mathrm{kcal}$, which is by quarter higher than in Ukraine. At the same time, the animal products share in the EU diet is at the same level. In relation to the structure of consumer food costs, there were no significant changes in comparison with the previous year, the places on expenditures as follows: meat and meat products $-24 \%$ (827 UAH per household per month), bread and bakery products - 15\% (511 $\mathrm{UAH})$, milk and dairy products - 14\% (494 UAH), fish and fish products $-5 \%$ (170 UAH), eggs - 3\% (102 UAH), sunflower oil and other oil products $-3 \%$ (102 UAH), fruits - 7\% (238 UAH), vegetables - 9\% (307 UAH), potato - 3\% (102 UAH), sugar - 8\% (273 UAH), non-alcoholic drinks - 6\% (204 UAH), other - 2\% (68 UAH) (Zaliznjuk, 2019).

Sustainable economic development of the state, improvement of welfare and living standards of the 
Proceedings of the 2019 International Scientific Conference 'Economic Sciences for Agribusiness and Rural Economy' No 3, Warsaw, 5-7 June 2019, pp. 95-102

Table 1. Consumption of basic food products by Ukraine population (kg per capita per year)

\begin{tabular}{|c|c|c|c|c|c|c|c|c|c|c|}
\hline \multirow[b]{2}{*}{ Indicator } & \multicolumn{10}{|c|}{ Food types } \\
\hline & 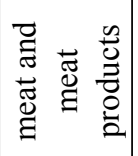 & 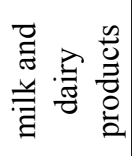 & 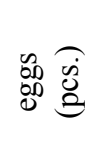 & 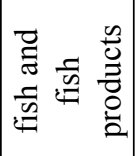 & 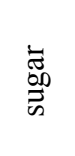 & 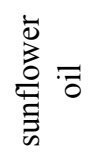 & 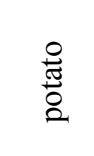 & 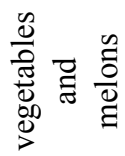 & 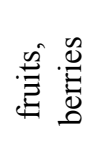 & 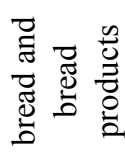 \\
\hline $\begin{array}{l}\text { Regional } \\
\text { nourishment norms }\end{array}$ & 80 & 380 & 290 & 20 & 38 & 13 & 124 & 161 & 90 & 101 \\
\hline $\begin{array}{l}\text { Minimal } \\
\text { nourishment norms }\end{array}$ & 52 & 341 & 231 & 12 & 32 & 8 & 96 & 105 & 68 & 94 \\
\hline 1990 & 68 & 373 & 272 & 17.5 & 50 & 11.6 & 131 & 102 & 47 & 141 \\
\hline 1995 & 39 & 244 & 171 & 3.6 & 32 & 8.2 & 124 & 97 & 33 & 128 \\
\hline 2000 & 32.8 & 199.1 & 166 & 8.4 & 36.8 & 9.4 & 135.4 & 101 & 29.3 & 124.9 \\
\hline 2005 & 39.1 & 225.6 & 238 & 14.4 & 38.1 & 13.5 & 135.6 & 120 & 37.1 & 123.5 \\
\hline 2010 & 52 & 206.4 & 290 & 14.5 & 37.1 & 14.8 & 128.9 & 143 & 48 & 111.3 \\
\hline 2015 & 51 & 210 & 280 & 8.6 & 36 & 12.3 & 138 & 161 & 51 & 103 \\
\hline 2016 & 51 & 210 & 280 & 8.6 & 36 & 12.3 & 138 & 161 & 51 & 101 \\
\hline 2017 & 51.7 & 200 & 273 & 10.8 & 30.4 & 11.7 & 143.4 & 159 & 52.8 & 100.8 \\
\hline 2017 in \% vs 1990 & 76.1 & 53.6 & 73.2 & 61.7 & 60.1 & 100.1 & 109.5 & 121.4 & 112.3 & 71.5 \\
\hline Minimal norms & 99.4 & 58.7 & 118.2 & 90 & 95 & 146.3 & 149.4 & 151.4 & 77.6 & 107.2 \\
\hline Rational norms & 71.4 & 52.6 & 94.1 & 54 & 80 & 90 & 115.6 & 98.8 & 58.7 & 99.8 \\
\hline
\end{tabular}

Source: FAO (2018).

population is impossible without the effective functioning of the agro-industrial sector. Agricultural production of today and the Ukrainian agro-industrial complex as a whole are at the centre of public attention, as our already poorly-off table has recently become particularly poor, the food prices have risen sharply, causing great concern for the Ukrainian population and sharpening social tensions. This situation has led to the search for new alternative types of food and income sources. One of these areas is nutria breeding, the current state of which indicates the existence of a certain set of problems that require in-depth study from different parties for further substantiation of the industry meaningful development strategies.

The main advantage of nutria breeding is the fact that this branch is one of the fastest growing, along with rabbit and poultry husbandry. Nutria females are naturally highly fertile farm animals that give birth to high-grade young animals. One nutria female provides about one kilo of meat and over 10 nutrias (skins) a year, as well as high-quality by-products: fat and manure, including offsprings. For high-fat characteristics, meat of nutria has been widely recognized as a dietary product. Meat yield depends on age, sex, and animal fat and ranges from $46 \%$ in young to $60 \%$ of live weight in adult males. By-products amount $4.5 \%$ (Table 2). One adult animal weighing 6-8 kg provides $3.2-4.3 \mathrm{~kg}$ of meat.

Nutria meat (without bones, intramuscular fat and by-products) is characterized by a high content of valuable protein and at the same time has a relatively low calorie content (Table 3).

The nutria meat by essential amino acids content is equivalent to beef and chicken, according to vitamin and mineral composition it is practically incommensurable with any other kind of meat. It is especially useful for people in need of complete protein 
Proceedings of the 2019 International Scientific Conference 'Economic Sciences for Agribusiness and Rural Economy' No 3, Warsaw, 5-7 June 2019, pp. 95-102

Table 2. Comparative characteristics of meat and by-products yield by animal species (\%)

\begin{tabular}{|l|c|c|c|c|}
\hline Type of animal & Meat with bones & By-products & Altogether & Hypodermic fat \\
\hline Nutria & 54.5 & 4.5 & 59.0 & 6 \\
\hline Rabbit & 56.9 & 3.8 & 60.7 & 7 \\
\hline Small hens & 58.0 & 6.0 & 64.0 & 7 \\
\hline Beef of $2^{\text {nd }}$ class & 46.0 & 2.8 & 59.0 & 3 \\
\hline
\end{tabular}

Source: Volkov (1983).

Table 3. Chemical composition of meat of main agricultural animals

\begin{tabular}{|l|c|c|c|c|}
\hline Indicators & Nutria & Rabbit & Beef & Chicken \\
\hline Water (\%) & $67-73$ & 69.3 & 72.2 & 72.8 \\
\hline Protein (\%) & 20.8 & 24.5 & 20.6 & 20.0 \\
\hline Fat (\%) & $4.1-10$ & 8.0 & 5.5 & 5.1 \\
\hline Minerals (\%) & 1.1 & 1.2 & 1.2 & 1.1 \\
\hline Caloric value (kcal) & $156-200$ & 168 & 178 & 166 \\
\hline
\end{tabular}

Source: Volkov (1983).

products. This meat contains by $50 \%$ more amino acids than in pork, and $4 \%$ more than in rabbit meat, nutria fat is a record-holder on the percentage of unsaturated fatty acids (up to $61.2 \%$ ). Compared to the meat of other animals, nutria meat has a significantly low cholesterol and sodium content, which makes it a very attractive product for healthy nutrition. The nutria meat is easily digestible by humans and is valued as a dietary product; in the European markets, it is by 2-3 times more expensive than other meat products.

In 2018 Ukraine produced 1,535 thousand $t$ of meat (all categories) in slaughter weight, which provide high-quality food for 18.7 million inhabitants (41.7\% of the population). The main share falls on the production of poultry meat $-70.7 \%$, pork $-23.4 \%$, beef and veal $-5.7 \%$, other species account for only $0.2 \%$ of total production (State Statistics Service of Ukraine, 2018). In the last 10-15 years the supply of beef meat in all regions has decreased, the cattle meat industry has become unprofitable. Pork production is unprofitable in 14 regions of the existing 25 , the most abandoned locations are in the Zhytomyr, Transcarpathian, Kirovograd, Mykolaiv, Odessa, Kharkiv, Chernihiv and other regions. The reason for such situation of the main meat sectors of Ukraine is that the animal productivity is low, and the cost of production is high, which causes losses. The nutria breeding, as practice shows, is one of the promising sectors of livestock farming in Ukraine, but for a long time (for over 25 years) it has not been given sufficient attention either from practical or scientific directions of development, and only from 2010 it begins its noticeable rise (Parhomec', 2015). Production of other animals' meat by species in slaughter weight is presented in Figure 1.

The data presented on Figure 1 show that in 2018 almost 50\% belongs to nutria breeding, which in comparison with 1990 has increased by 5 times. In natural terms, this figure is 1.4 thousand tons of meat, which makes it possible to feed 17 thousand inhabitants of the country ( $0.04 \%$ of Ukraine population). Here it is necessary to clarify that the data presented is related only to agricultural enterprises. At first glance, this data is quite insignificant, but on the other hand, taking into account the industry's potential, its speed and profitability rate of almost $70 \%$, the nutria breeding can become one of the alternative sources of meat products supply to the population. What is actually happening, because $80 \%$ of the industry is concentrated in population households (Fig. 2, for example, Dnipropetrovsk region). 


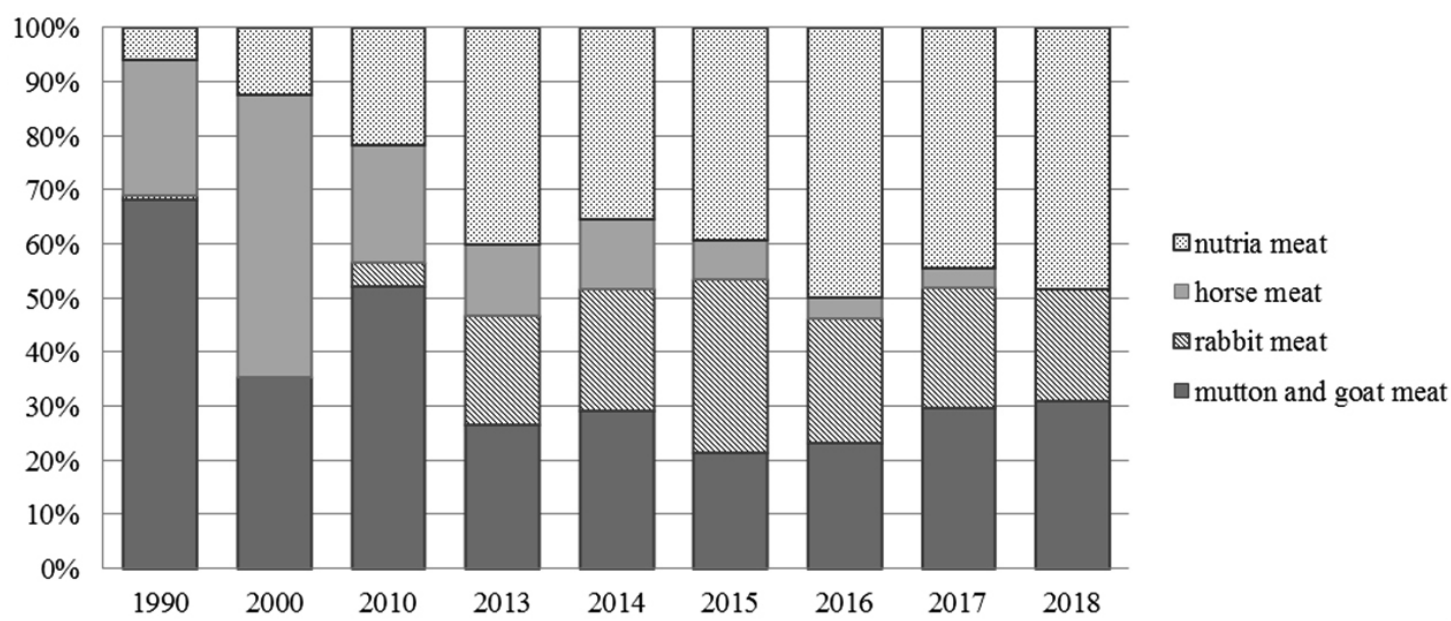

Figure 1. Production of other animal meat (by species) in slaughter weight in Ukraine

Source: State Statistics Service of Ukraine (2018).

The data presented on the Figure 2 show that during the construction of the trend line and the regression equation by $58 \%$, in the next two years, an increase in the number of livestock in nutria breeding enterprises will occur, but the situation is still unstable. Analysis of activity at the level of specific farms, especially enterprises in the Dnipropetrovsk region shows contradictory results. At the same time, the nutria breeding branch began to recover gradually, first of all in Dnipropetrovsk region. There, as of
1 January 2018, the total number of nutria in agricultural organizations, farms and population households amounted 11,394 heads. The dynamics of the economic efficiency development of the nutria breeding branch in agricultural holdings is given in Table 4.

The given indicators of Dnipropetrovsk region nutria breeding enterprises showed high economic efficiency of this type of business. For example, in 2017 the regional nutria population has been increased: by 1.7 times; receipts from sales of products by 3.5

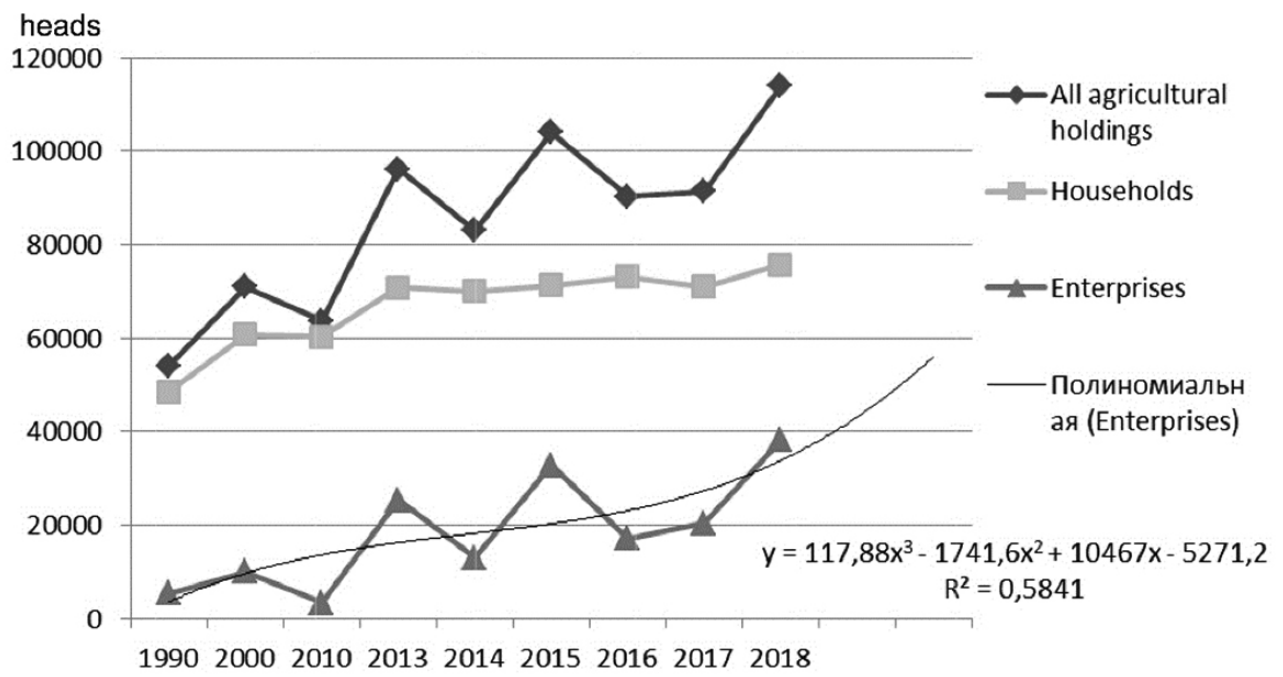

Figure 2. Dynamics of nutria population by household types in the Dnipropetrovsk region, Ukraine Source: State Statistics Service of Ukraine (2018). 
Proceedings of the 2019 International Scientific Conference 'Economic Sciences for Agribusiness and Rural Economy' No 3, Warsaw, 5-7 June 2019, pp. 95-102

Table 4. Results of coypu husbandry enterprises activity in Dnipropetrovsk region

\begin{tabular}{|l|r|r|r|r|r|r|r|}
\hline Indicator & \multicolumn{1}{|c|}{2007} & 2009 & 2011 & 2013 & 2015 & 2017 & $\begin{array}{c}2017 \text { in \% } \\
\text { vs } 2007\end{array}$ \\
\hline Sold animals - in total & 11812 & 5901 & 10233 & 18641 & 19114 & 20413 & 17282 \\
\hline including: live weight for breeding & 1094 & 728 & 1015 & 1899 & 2001 & 1984 & 181.35 \\
\hline Average body weight (kg) & 3.9 & 4.2 & 3.8 & 3.5 & 3.6 & 3.8 & 97.44 \\
\hline General expenditures (thous. UAH) & 1577.8 & 1192.1 & 1415.3 & 3786.6 & 3968.3 & 3994.2 & 253.15 \\
\hline Receipts - in total (thous. UAH) & 2041.9 & 1200.8 & 2030.9 & 5547 & 6849.2 & 7133.9 & 349.38 \\
\hline Profit (thous. UAH) & 464.1 & 8.7 & 615.6 & 1760.4 & 2880.9 & 3139.7 & 676.51 \\
\hline Profitability level (\%) & 29.4 & 0.7 & 43.5 & 46.5 & 72.60 & 78.61 & 49.21 \\
\hline
\end{tabular}

Source: calculated according to the reports of the studied enterprises.

times; the profit mass - by 6.7 times. The profitability level of the region's nutria breeding was $78.61 \%$, which is by 49 points more than in 2007 . In the structure of production costs, the largest expenditures are attributed to such indicators as: feed costs (40.8\%), wages $(33.9 \%)$, depreciation $(17.5 \%)$.

Sharp fluctuations of line in Figure 2 point to existing development problems that need to be understood, and in the absence of a large array of statistical data, this can be done using the expert estimation method, the results of which will serve as the basis for making managerial decisions for the development of further strategies for sustainable development. For a full-fledged analysis, only quantitative indicators are insufficient, important role belongs to a qualitative component.

There are many factors affecting the industry development. Production of this type of products may be carried out in two dimensions: at the enterprises and in households. The main powerful productive force is nutria breeding enterprises, which in the future, when forming an integration association, will become the basis for the industry development. To obtain independent conclusions, there were interviewed 10 experts in the field of nutria breeding production of Dnipropetrovsk region, all of them are leading specialists of the abovementioned enterprises. Experts are invited to assess five production risk factors of nutria breeding by their importance and assign a maximum score to the most significant risk on the one hundred scale, and minimal for the least significant.
Table 5 shows the values assigned to each production risk factor for the nutria breeding enterprises by all experts. Each factor is assigned a number: 1 - the technology intensity; 2 - establishment of the sales markets system for the production of nutria products, standardization and certification of product quality; 3 - state support for nutria breeding industry; 4 - interconnection and integration of business entities in the industry; 5 - natural and climatic conditions, fashion and consumer awareness about the dietary and healing properties of nutria meat products.

When ranking objects as a measure of expert opinions consistency, the dispersion coefficient of concordance is being used (Grabovec'kyj, 2010).

Let us consider the matrix of ranking results $m(5)$ - risks $d(10)$ - experts $\left|r_{i s}\right|(s=\overline{1, d} ; i=\overline{1, m})$, where $r_{i s}$ - rank given by the $s$-expert of $i$-risk. We add the sum of the ranks for each risk, as a result of which we obtain a vector with the components: $r_{i}=\sum_{s=1}^{d} r_{i s}(i=\overline{1, m})$.

We shall consider the values of $r_{i}$ as realization of a random variable and we will find a dispersion estimation. As it is known, the optimal by minimum criterion of the average square error the dispersion estimate is being found according to the formula

$$
D=\frac{1}{m-1} \sum_{i=1}^{m}\left(r_{i}-\bar{r}\right)^{2}=862
$$


Proceedings of the 2019 International Scientific Conference 'Economic Sciences for Agribusiness and Rural Economy' No 3, Warsaw, 5-7 June 2019, pp. 95-102

Table 5. Results of ranked assessments of experts of Dnipropetrovsk oblast

\begin{tabular}{|c|c|c|c|c|c|c|}
\hline \multirow{3}{*}{ Number of expert } & \multicolumn{5}{|c|}{ Number of risk factor } & \multirow{3}{*}{ Sum } \\
\hline & 1 & 2 & 3 & 4 & 5 & \\
\hline & \multicolumn{5}{|c|}{ rank } & \\
\hline 1. Pryzma Ltd. & 4 & 5 & 1 & 3 & 2 & 15 \\
\hline 2. Konar Ltd. & 3 & 5 & 2 & 4 & 1 & 15 \\
\hline 3. Khutriane Ltd. & 3 & 5 & 2 & 4 & 1 & 15 \\
\hline 4. MAKSITEK Ltd. & 4 & 5 & 2 & 3 & 1 & 15 \\
\hline 5. Vyshneve Ltd. & 3 & 5 & 2 & 4 & 1 & 15 \\
\hline 6. Farm Nahaichenko & 3 & 5 & 1 & 4 & 2 & 15 \\
\hline 7. Farm Ranok & 5 & 4 & 2 & 3 & 1 & 15 \\
\hline 8. Farm Kalynivka & 3 & 4 & 1 & 5 & 2 & 15 \\
\hline 9. Standart Ltd. & 3 & 5 & 2 & 4 & 1 & 15 \\
\hline 10. Organika Ltd. & 3 & 5 & 2 & 4 & 1 & 15 \\
\hline Sum of ranks & 34 & 48 & 17 & 38 & 13 & 150 \\
\hline Average meaning & 0.227 & 0.320 & 0.113 & 0.253 & 0.087 & 1 \\
\hline
\end{tabular}

Source: calculated according to survey of the studied enterprises experts.

where $\bar{r}$ is the estimate of the mathematical expectation equal to

$$
\bar{r}=\frac{1}{m} \sum_{i=1}^{m} r_{i}=30
$$

Let us give the designation

$$
S=\sum_{i=1}^{m}\left(\sum_{s=1}^{d} r_{i s}-\bar{r}\right)^{2}
$$

Concordance coefficient

$$
W=\frac{12 \cdot S}{d^{2} \cdot\left(m^{3}-m\right)}=0.862
$$

The presented formula defines the concordance coefficient in the absence of interrelated ranks, which fully satisfies our conditions.

The concordance coefficient is equal to one, if all the ranking of experts are the same, and is equal to zero, if all the ranks are different. To determine the significance of the concordance coefficient estimat- ing, it is necessary to know the frequency distribution for different values of the number of experts $d$ and the number of risks $m$. The frequency distribution for $W$ at various values of $m$ and $d$ can be determined by statistical tables. To do this, one uses the Spearman criterion $\chi^{2}$. If the criterion value is more than critical, which was taken from the table of critical values of the Pearson distribution for a given significance level and the number of degrees of freedom $\chi^{2}=(\alpha=0.05$; $k=4)=9.49$, then the concordance coefficient is statistically significantly different from zero and the opinion of the experts is considered concordant.

$$
\chi^{2}=W \cdot d(m-1)=34.48 \geq 9.49
$$

In terms of production risk factors weight percentages for the coypu husbandry enterprises, they were distributed as follows: the establishment of sales markets system for the nutria breeding products, standardization and certification of product quality $-40.6 \%$; interconnection and integration of business entities of the industry $-25.2 \%$; availability of intensive technology $-19.9 \%$; state sup- 
port $-8.7 \%$; natural and climatic conditions, fashion and consumer awareness about dietary and healing properties of nutria meat $-5.6 \%$. These very factors significantly restrict the efficiency increase and sustainable development of the industry enterprises.

\section{CONCLUSIONS AND DIRECTIONS OF FURTHER RESEARCH}

We believe that nutria breeding can take a significant place in the peasants' lives, can improve their economic and social conditions, can increase number of job places and employment in each region of Ukraine. It is important to take into account that the nutria meat from a social point of view is useful to society as a dietary product that has healing properties and can positively affect the population health. At the same time nutria meat, having dietary and prophylactic properties, is in high demand in the countries of Europe, the USA, China, Japan and other countries of the world. Taking into account this fact, our entrepreneurs should pay considerable attention and increase investment resources precisely for the development of the nutria breeding industry.

With a comprehensive strategic approach to this industry prospects, there will appear all opportunities for the nutria breeding development on the basis of small business and ultimately, due to integration processes, there can be considerably improved the economic efficiency of the nutria enterprises. There is an economic and social expediency of the nutria breeding industry production increase in each region of Ukraine, which will enable not only to improve the balance of dietary meat production and consumption, yet also to increase export deliveries of this product, lay the foundation for the development of a very important and necessary livestock branch alternative in the context of Ukraine's food security.

\section{REFERENCES}

1. Derzhavna sluzhba ststystyky Ukrainy [State Statistics Service of Ukraine] (2018). Retrieved from: http:// www.ukrstat.gov.ua
2. FAO (2018). The food insecurity experience scale. Retrieved from: http://www.fao.org/in-action/voices-ofthe-hungry/fies/en/.

3. Grabovec'kyj, B. (2010). Metody ekspertnyh ocinok: teorija, metodologija, naprjamky vykorystannja [Methodology expert evaluations: theory, methodology, direct reading]. VNTU, Vinnytsia.

4. Kyrylenko, V. (2014). Ekonomichna bezpeka agrarnogo sektoru: problemy reguljuvannja ta zabezpechennja [Economic security of the agrarian sector: problems of regulation and provision]. Mykolai'v: Vydavec' V.P. Shamraj.

5. Parhomec', M. (2015). Organizacijno-ekonomichni zasady zbil'shennja obsjagiv vyrobnyctva dijetychnogo m'jasa v Ukrai'ni [Organizational and economic principles of increasing the production of dietary meat in Ukraine]. Teoretychni ta prykladni aspekty rozvytku agrarnogo biznesu Ukrai'ny: materialy Vseukr. nauk.-prakt. konf. z mizhnar. Uchastju, Ternopil': Ekonomichna dumka, pp. 189-193.

6. Pogrishhuk, B. (2019). Ekonomichna bezpeka agrarnogo sektoru u systemi ekonomichnoi' bezpeky derzhavy [Economic security of the agrarian sector in the system of economic security of the state]. Naukovyj visnyk Uzhgorods'kogo universytetu. Ekonomika, 1 (53), pp. 48-52.

7. Rozporiadzhennia Kabinetu Ministriv Ukrainy "Strategija rozvytku agrarnogo sektoru ekonomiky na period do 2020 roku" No 806-r vid 17 zhovtnja 2013 r. Ofitsiynyy Visnyk Ukrayiny 2013 No 83 (05.11.2013), st. 23 [Regulation of Cabinet of Ministers of Ukraine "Strategy for the development of the agrarian sector of the economy until 2020" of 17.10 .2013 No 806-r. Official Bulletin of Ukraine 2013, No 83 (05.11.2013), p. 23].

8. Vasylieva, N. (2018). Ukrainian Agricultural Contribution to the World Food Security: Economic Problems and Prospects. Montenegrin Journal of Economics, 14 (4), pp. 215-224, https://www.doi.org/10.14254/1800-5845/ 2018.14-4.15

9. Volkov M. (1983). Myasnaya produktivnost' nutrii [Nutria meat productivity]. Krolikovodstvo i zverovodstvo, 17.

10. Zaliznjuk, V. (2019). Ocinka indykatoriv prodovol'choi' bezpeky Ukrai'ny [Estimation of food safety indicators of Ukraine]. Investycii': praktyka ta dosvid, 2, pp. 128-133, https://www.doi.org/10.32702/2306-6814. 2019.2.128 